\title{
Homocitrulline Measurement
}

National Cancer Institute

\section{Source}

National Cancer Institute. Homocitrulline Measurement. NCI Thesaurus. Code C154758.

The determination of the amount of homocitrulline present in a sample. 